\title{
Terme in die Molekulêre Biologie
}

\author{
D.F. Louw \\ Inligtings- en Navorsingsdienste, WNNR, Posbus 395, Pretoria 0001
}

Dit moet allerweë verwelkom word dat mense soos proff. Potgieter en Prozesky die moeite doen om termelyste vir kennisname (en vermoedelik ook vir kommentaar) te publiseer vir gebiede waarvoor daar nog geen vakwoordeboeke bestaan nie. ${ }^{1}$ Die byvoeging van termverklarings maak die lyste besonder waardevol, maar 'n mens kan miskein net vra of die ekwivalente Engelse terme nie ook maar volledigheidshalwe bygevoeg kon gewees het nie. Op dié manier kan die terminologie op "nuwe" vakgebiede enigsins gestandaardiseer word, want die gevaar bestaan dat navorsers en dosente anders elkeen hul eie terme skep en so aan 'n Babelse spraakverwarring meehelp.

Omdat sommige terme in die gepubliseerde lys vir die molekulêre biologie 'n "chemie-inhoud" het, verdien hulle oorweging by die bewerking van die hersiene Chemiewoordeboek. Die volgende opmerkings is derhalwe bedoel om uit dié oogpunt sekere probleme uit te wys waaroor daar verder besin moet word: -

- Aanvangskodon word as alternatief vir beginkodon gegee. Die term aanvangsfaktor is ook opgeneem. Verskeie biochemici het reeds besluit om initiation codon (initiator codon) met aanvoorkodon of inisieerkodon te vertaal.

Vir sommige is aanvang 'n Germanisme. Daar is ook die probleem dat aanvang hom moeilik in hierdie verband as werkwoord laat gebruik; hier is aanvaar en inisieer baie bruikbaarder. Dieselfde argumente is by aanvangsfaktor ter sprake. Dit het moontlik voordele om terme soos inisieer, inisiëring en inisieerkodon te gebruik omdat hulle in heelparty ander tale herkenbaar is. Vergelyk in hierdie verband attenueerdergebied, immuniteit, ens. (Terloops, die afkortings $A U G$ en $G U G$ word nie omskryf nie).

- AASS. Vermoedelik het 'n spelfout die koppelteken in antiliggaam-afhanklike selbemiddelde sitotoksisiteit laat wegval, maar daar kon ook vas (sonder koppelteken) geskryf gewees het. Dit word verwelkom dat Afrikaanse afkortings vir hierdie soort terme gebruik word naas die internasionaal aanvaarde afkortings vir chemiese verbindings soos DNA.

- Antiliggaam. Die term teenliggaam verskyn onder andere in Brink se Woordeboek van Afrikaanse Geneeskundeterme en is reeds ingeburger.

- CAP. Dit is nie 'n afkorting van 'n chemiese naam soos DNA nie, maar staan vir katabolietgeenaktiveringsproteien. Soos Brink MGH (menslike groeihormoon) gebruik as ekwivalent vir $\mathrm{HGH}$ (human growth hormone) in Engels, kan liewer oorweeg word om $K A P$ te gebruik. Dan is verwarring met cap ook nie moontlik nie - indien laasgenoemde nog gebruik gaan word.

- Colifaag. Terblanche se Tegniese Woordeboek gee kolifaag aan. Brink, asook Snyman in sy Geneeskundige Woordeboek, skryf koli- in terme soos kolibakterie en kolivorm(ig). Hierteenoor is Escherichia coli natuurlik korrek en verskyn gewoonlik in skuinsdruk.

- Hemagglutinasie en hemagglutinien. In Engels word gewoonlik haem- in samestellings geskryf, en hem- in Amerikaanse publikasies. Dit is reeds ' $n$ vaste gebruik om in Afrikaans heem- te skryf in hierdie soort samestelling, en ook as selfstandige naamwoord heem ('n pirroolderivaat). Die verbindingsvorme hema- en hemo-, soos in hematologie en hemoglobien, is ook goed bekend.

- Ikosahedron. In Duits word Eikosa- en in Engels eicosa-geskryf, maar in Nederlands wel ikosa-. In die Chemiewoordeboek word egter reeds sedert die eerste uitgawe eikosa- geskryf.

- Klewerige ente. Dit is maar ' $n$ "taai" term in hierdie verband! Ook saamklewende eindpunte hinder. Kleefeindpunte/kleefente is miskien al iets beter, maar hegeindpunte of laseindpunte kan dalk oorweeg word.

L-ketting, l-ketting. Dit lyk nie wenslik om slegs deur hoof- en kleinletters tussen totaal verskillende verbindings te onderskei nie. As die term aan die begin van 'n sin staan, sal die verskil in elk geval verdwyn. Ander oplossings moet derhalwe bedink word; hoofletters in al hierdie gevalle sou verkieslik wees.

- Limfokiniene. Hierdie verbindings is nie kinienderivate nie, maar wel peptiede. Om verwarring te voorkom, word voorgestel dat limfokinin (enkelvoud) en limfokininne (meervoud) geskryf word. In Duits word reeds Kinin en in Nederlands kinin geskryf waar hierdie soort verbindings ter sprake is, naas onderskeidelik Chinin en chinine/kinine vir wat in Engels quinine genoem word. Daar moet dus ook bradykinin, sitokinin, ens. geskryf word.

Superdraai. In die definisie word die term heliks gebruik wat in hierdie verband al ingeburger is. Dit lyk asok superheliks verkieslik is, soos ook deur biochemici aanvaar word.

Vertaling. Kyk ook keepvertaling. Om die Engelse term translation in hierdie verband so te vertaal, kom tog 'n bietjie vreemd voor. 'n Hele aantal biochemici het al tot tolking (alternatief 
translasie) besluit, maar miskien kan 'n nog geskikter term geskep word eerder as om 'n onbevredigende term deur vertaling te vorm. Dink hierby gerus ook aan transkripsie, transfeksie, transduksie, transposisie, transversie, ens.

- Xenogenies. Dit is seker net 'n setfout. Vergelyk dit met isogeneïes en singeneïes.

Die lysie is hiermee seker nie uitgeput nie, maar behoort te toon dat daar met omsigtigheid te werk gegaan moet word wanneer nuwe vakterme geskep en in publikasies - veral in termelyste - gebruik word. Daar moet so ver moontlik voorkom word dat ongewenste of foutiewe terme deur herhaalde gebruik ingeburger raak.

\section{VERWYSINGS}

1. Potgieter, H.J. en Prozesky, O.W. (1983). Verklarende Woordelys van terme in die Molekulêre Biologie. S.A. Tydskrif Natuurwetenskap en Tegnologie, 1, 167-174. 